\title{
Effects of Nutrient Levels and Rice Cultivation on Taxonomic and Functional Diversity of Bacterial Communities in Flooded Soils of the Hanon Maar Crater, Korea
}

\author{
Jinu Eo * and Myung-Hyun Kim
}

check for

updates

Citation: Eo, J.; Kim, M.-H. Effects of Nutrient Levels and Rice Cultivation on Taxonomic and Functional Diversity of Bacterial Communities in Flooded Soils of the Hanon Maar Crater, Korea. Agronomy 2022, 12, 651. https://doi.org/10.3390/ agronomy12030651

Academic Editors: Blanca R. López and Luz E. de-Bashan

Received: 27 January 2022

Accepted: 4 March 2022

Published: 7 March 2022

Publisher's Note: MDPI stays neutral with regard to jurisdictional claims in published maps and institutional affiliations.

Copyright: (c) 2022 by the authors. Licensee MDPI, Basel, Switzerland. This article is an open access article distributed under the terms and conditions of the Creative Commons Attribution (CC BY) license (https:// creativecommons.org/licenses/by/ $4.0 /)$.
National Institute of Agricultural Sciences, Rural Development Administration, Wanju 55365, Korea; wildflower72@korea.kr

* Correspondence: eojiny@korea.kr

\begin{abstract}
Agricultural land use may deteriorate soil bacterial diversity and function in an agroecosystem. This study aimed to explore the impact of agricultural disturbance on the taxonomic and functional diversity of soil bacteria using a high-throughput sequencing method. We examined the bacterial community diversity in five types of flooded soils in the Hanon Maar Crater from two types of canals characterized by different nutrient levels and three field types with a different rice cultivation history. Proteobacteria (43.2\%), Chloroflexi (19.8\%), Acidobacteria (15.8\%), Actinobacteria (5.1\%), and Nitrospirae $(5.0 \%)$ were the dominant phyla $(>5 \%)$. The relative abundance of Actinobacteria was 7.1 times greater in the abandoned fields than in the polluted canal. Alpha diversity indices of taxonomic diversity showed strong negative correlations with $\mathrm{C}, \mathrm{N}$, and $\mathrm{NH}_{4}{ }^{+}$levels. The 1.7 -fold greater number of operational taxonomic units (OTUs) in abandoned fields than in paddy fields may be caused by factors other than nutrients. Functional analysis revealed that 11 putative functions, including cellulolysis and ligninolysis, were significantly affected by soil management. Functional diversity indices showed negative correlations with electrical conductivity (EC) and $\mathrm{NH}_{4}{ }^{+}$. Nitrogen input had a greater effect on bacterial taxonomic diversity than on functional diversity. Available $\mathrm{P}$ was positively correlated with the diversity indices. Taken together, these results suggest that keeping land fallow for more than 5 years and monitoring of $\mathrm{C}, \mathrm{N}$, and $\mathrm{P}$ levels are practical approaches for restoring taxonomic diversity but not functional diversity of soil bacteria. Our study demonstrated a decoupled response of taxonomic and functional diversity to rice cultivation, highlighting the necessity of further studies on the impact of decoupling on the stability of ecosystem functioning.
\end{abstract}

Keywords: nitrogen; phosphorus; function; restoration; sustainability

\section{Introduction}

Maars are shallow volcanic craters formed during phreatomagmatic explosions [1]. The Hanon Maar Crater, created approximately 3.4 million years ago on Jeju Island, is the only maar-type crater on the Korean Peninsula [2]. Located at the center of the Hanon Volcano, it is approximately $1.0-1.2 \mathrm{~km}$ in diameter. Approximately 500 years ago, the side wall of the crater was pulled down for drainage, and crop cultivation was started there [3]. Rice cultivation has been done mainly in the low ground via irrigation with spring water [4]. Volcanic craters are valuable resources for obtaining climatic and ecological data on microbes and other biota [5,6]. Because of the historical and ecological importance of the Hanon Maar Crater, efforts have been made to restore its ecosystem. An important goal of such restoration is to preserve the soil, which provides valuable archaeological and geochemical data, which are, in turn, useful for research on climatic change [7].

Soil bacteria are important in the multiple functions of soil, including organic matter decomposition, nutrient cycling, and aggregate formation [8,9]. In turn, soil nutrients are critical factors influencing bacterial communities [10]. The agricultural practice of fertilization disturbs the biotic and abiotic environments of the soil ecosystem. The application 
of organic and inorganic fertilizers changes the chemical properties of soil, such as $\mathrm{pH}$ and nutrient conditions [11,12]. Fertilizers spread from soil to aquatic systems through drainage and underground leakage. Leached fertilizers are non-point sources of aquatic pollution and cause eutrophication and influence soil bacteria in aquatic habitats $[13,14]$. Moreover, craters on islands are geographically isolated habitats that are vulnerable to environmental disturbances.

Biodiversity is an important ecological indicator in the restoration of various ecosystems $[15,16]$. Restoration practices increase ecosystem functioning by promoting the recovery of biodiversity [17]. Issues of microbial biodiversity encompass sustainable development in relation to ecosystem services [18]. Agricultural practices may decrease soil ecosystem sustainability with regard to bacterial diversity [19]. Ecosystem biodiversity helps in maintaining stability against environmental stress and ecological disturbance. In this context, there is great interest in determining whether reducing agricultural disturbances promotes the restoration of bacterial communities [20].

Soil nutrient management is critical for the conservation of bacterial diversity, leading to improved soil functions and crop production [21]. Bacterial communities are associated with soil nutrient availability and enzyme activity [22]. The excessive use of fertilizers leads to the deterioration of bacterial diversity, and reducing fertilizer use is an environmentally friendly way to improve the soil ecosystem [23]. However, it is feared that reduced nutrients may cause a decrease in crop yield. Optimizing fertilization practice is necessary to balance soil bacterial diversity and agricultural production [24]. Hence, a recommendation for soil nutrient levels is necessary for a practical approach to achieve these goals.

The diversity of soil bacteria is assessed in terms of taxonomic and functional diversity. Taxonomic diversity, a critical component supporting ecosystem sustainability, is a good indicator of a healthy ecosystem [18]. Functional diversity influences metabolic activity in the ecosystem, and maintenance of various functional bacterial communities is essential for sustainable agriculture [19]. Bacterial diversity and functions are closely associated with soil habitat and are used to assess environmental quality [25,26]. Conventional culture-dependent methods measuring bacterial functions are limited to cultivable species and cycling of specific materials $[27,28]$. However, recent advances in predicting bacterial function based on genetic and taxonomic analysis have been applied to analyze the bacterial community to overcome these problems.

Taxonomic and functional diversity are key components supporting ecosystem functions. Management of agricultural soil bacteria requires an understanding of ecological processes that mediate how agricultural practice influences bacterial functions. The aims of the present study are as follows: (1) to compare the composition and diversity of bacterial communities in flooded soils under different agricultural uses and (2) to investigate the changes in bacterial functions in response to chemical disturbance caused by nutrient input. Bacterial community diversity was compared among five different types of soils subjected to different levels of nutrients and agricultural management. This study was designed to simultaneously analyze soil bacteria's taxonomic and functional diversity. Further, sequencing-based approaches were used to fully analyze the putative functions of cultivable and uncultivable bacteria.

\section{Materials and Methods}

\subsection{Study Site}

The Hanon Maar Crater is located on Jeju Island, Republic of Korea $\left(33^{\circ} 15^{\prime} 06^{\prime \prime} \mathrm{N}\right.$, $\left.126^{\circ} 32^{\prime} 43^{\prime \prime} \mathrm{E}\right)$, at an altitude of $750-850 \mathrm{~m}$. The annual mean temperature is $16.6^{\circ} \mathrm{C}$, and the annual mean precipitation is $1923 \mathrm{~mm}$. The crater is $1.0-1.1 \mathrm{~km}$ in diameter and has an area of 127.6 ha. The crater currently contains agricultural fields that are used to cultivate rice, fruit, and vegetables, with crop selection depending on the altitude of a particular site. Paddy fields are mainly located in the northern part of the crater (Figure 1). The flooded soils in the crater were grouped into five types, including two types of canals and three types of fields according to agricultural use. Two types of canal soil were selected 
according to the degree of nutrient pollution. The unpolluted canal soil was continuously provided with fresh water from a spring. The polluted canal was located at the end of the canal system, and nutrients mainly came from nearby paddy fields. Synthetic fertilizer and manure composts were applied as basal fertilizer, and urea was used as additional fertilizer in paddy fields of this area. Three types of field soil comprised soils in paddy, fallow, and abandoned fields. The fallow fields had not been cultivated for 1-3 years and were sparsely located among cultivated fields. The abandoned fields were located in the eastern part of the crater and had not been cultivated for 5-6 years. The dominant plant species are shown in Table 1.

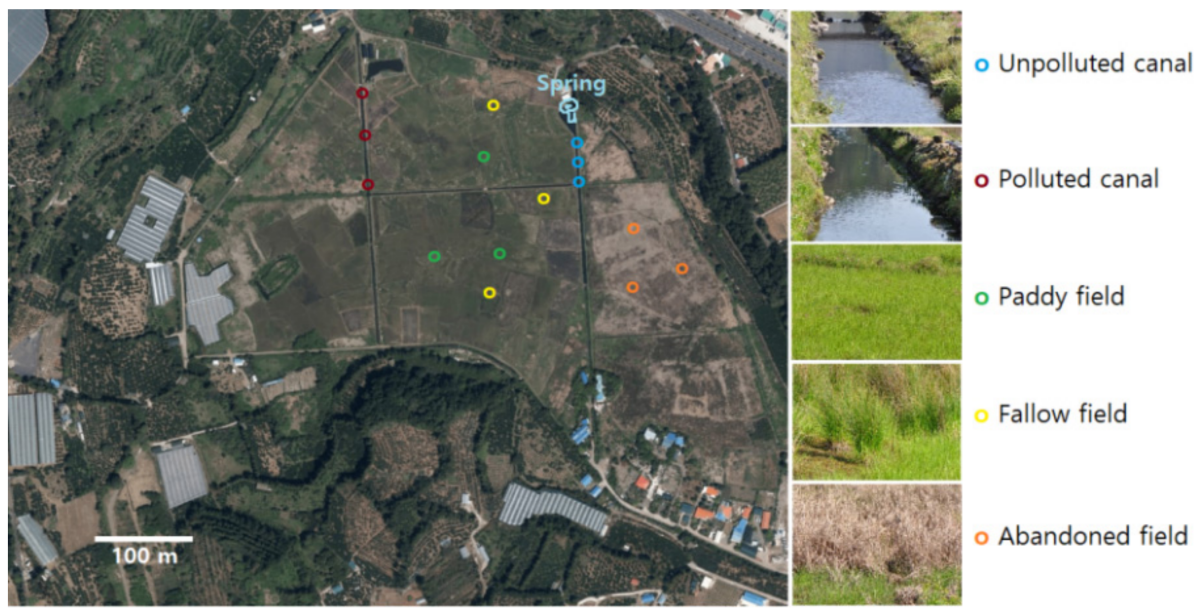

Figure 1. Survey sites in Hanon Marr crater. The photograph was obtained from Naver (www.naver.com, accessed on 8 December 2021).

Table 1. Composition of dominant plant species.

\begin{tabular}{cc}
\hline & Dominant Species \\
\hline Unpolluted canal & Zizania latifolia, Hydrilla verticillata, Potamogeton cristatus \\
Polluted canal & Hydrilla verticillata, Leersia japonica, Nasturtium officinale \\
Paddy field & Alopecurus aequalis, Aneilema keisak, Eclipta prostrata \\
Fallow field & Juncus effuses, Hydrocotyle sibthorpioides, Stellaria alsine, Aneilema keisak \\
Abandoned field & Echinochloa crusgalli, Aneilema keisak, Lemna perpusilla, Eleocharis acicularis \\
\hline
\end{tabular}

\subsection{Soil Sampling and Analysis of Chemical Properties}

Soil sampling was conducted before the rice-growing season on 23 April 2015; the sampling sites are depicted in Figure 1 . Soils were sampled at a depth of $0-10 \mathrm{~cm}$ using a soil sampler at three replicate plots $(8 \times 4 \mathrm{~m}$ each). The canal soils were collected from the side wall of the canals. Samples collected from four to five places at each plot were pooled. Fifty grams of soil was freeze-dried and then preserved at $-72{ }^{\circ} \mathrm{C}$ for sequencing analysis. Soils for chemical analysis were air-dried, and plant debris was carefully removed. Soil $\mathrm{pH}$ and EC were measured in a 1:5 (soil:water) suspension by $\mathrm{pH}$ meter and conductivity meter, respectively. $\mathrm{NH}_{4}{ }^{+}$and available $\mathrm{P}$ were extracted with $2 \mathrm{M} \mathrm{KCl}$ and acetate-lactate buffer, respectively. These nutrients were measured using a SmartChem autoanalyzer (Westco, Italy) in accordance with the manufacturer's manual. The levels of C and $\mathrm{N}$ were determined using a CN analyzer, in accordance with the manufacturer's instructions (Vario Max CN, Elementar, Langenselbold, Germany).

\subsection{DNA Extraction, PCR Amplification, and Sequencing}

Total DNA was extracted from $0.5 \mathrm{~g}$ soil using the FastDNA ${ }^{\circledR}$ SPIN Kit for Soil (MP Biomedicals, Solon, OH, USA). PCR was performed using a Peltier Thermal Cycler (PTC200; MJ Research, Waltham, MA, USA). The V3-V4 region of the bacterial 16S rRNA 
gene was amplified using fusion primers 341F (5'-AATGATACGGCGACC-XXXXXXXXTCGTCG GCAGCGTC-AGATGTGTATAAGAGACAG-CCTACGGGNGGCWGCAG-3' and 805R (5'-CAAGCAGAAGACGGCATACGAGAT-XXXXXXXX-GTCTCGTGGGCTCGGAGATGTGTATAAGAGACAG-GACTACHVGGGTATCTAATCC- $3^{\prime}$ ). The amplification cycle consisted of an initial denaturation step of $3 \mathrm{~min}$ at $95{ }^{\circ} \mathrm{C}$, followed by 25 cycles of $30 \mathrm{~s}$ at $95{ }^{\circ} \mathrm{C}, 30 \mathrm{~s}$ at $55^{\circ} \mathrm{C}$, and $30 \mathrm{~s}$ at $72{ }^{\circ} \mathrm{C}$. PCR products were verified using $1 \%$ agarose gel electrophoresis and cleaned using CleanPCR (CleanNA, Waddinxveen, The Netherlands). The product quality and size were assessed using a DNA 7500 chip on a Bioanalyzer 2100 (Agilent, Palo Alto, CA, USA). Mixed amplicons were pooled, and sequencing was conducted with the Illumina MiSeq Sequencing system (Illumina, San Diego, CA, USA) [29].

\subsection{Bioinfomatics Analysis}

Chimeric reads were filtered on the basis of $<97 \%$ similarity by reference-based chimera detection using the UCHIME algorithm [30] and the non-chimeric 16S rRNA database from EzBioCloud [31]. OTUs with single reads were excluded from further analysis. Functions of culturable bacteria were assigned on the basis of Functional Annotation of Prokaryotic Taxa (FAPROTAX), and their functions were estimated by the relative abundance of bacteria assigned to each function [32]. For further functional analysis of bacteria, including unculturable OTUs, the $16 \mathrm{~S}$ rRNA sequencing reads were analyzed using the EzBioCloud Microbiome Taxonomic Profiling (MTP) pipeline. The pipeline predicts Kyoto Encyclopedia of Genes and Genomes (KEGG) pathways using the Phylogenetic Investigation of Communities by Reconstruction of Unobserved States (PICRUSt) algorithm [33,34].

\subsection{Statistical Analysis}

For significant ANOVA results, a Tukey test was performed to examine the significant differences $(p<0.05)$ among the variables, bacterial community and soil chemical properties. Pearson's correlation analysis was performed between soil chemical properties and bacterial community characteristics. These tests were performed using SAS v9.1 (SAS Institute Inc., Cary, NC, USA). Diversity indices, including the Shannon index $\left(\mathrm{H}^{\prime}\right)$ and inverse Simpson index (1/D), were calculated to estimate alpha diversity. The similarity between bacterial communities was analyzed using the Fast UniFrac online tool for principal coordinate analysis (PCoA). These analyses were performed in EzBioCloud 16S-based MTP (ChunLab, Seoul, Korea). Analysis of similarities (ANOSIM) was performed to analyze the significance of differences between bacterial communities using the vegan package in $R$ (version 3.4.3) [35].

\section{Results}

\subsection{Soil Chemical Properties}

Soil chemical properties were influenced by agricultural land use. The unpolluted canal soil showed relatively lower nutrient levels; in contrast, the polluted canal had eutrophic soil with higher nutrient levels (Table 2). Polluted canal soil had higher $\mathrm{C}$ and $\mathrm{N}$ levels than unpolluted canal soil, and it had the highest $\mathrm{EC}$ and $\mathrm{NH}_{4}{ }^{+}$concentrations among all five types of soil. However, no significant differences were identified in the measured soil chemical properties among the three types of fields associated with rice cultivation (Table 2). 
Table 2. Chemical properties of studied soils.

\begin{tabular}{|c|c|c|c|c|c|c|}
\hline & $\mathrm{pH}$ & $\mathrm{EC}\left(\mathrm{ds} \mathrm{m^{-1 } )}\right.$ & $\mathbf{N}(\%)$ & C (\%) & $\begin{array}{c}\mathrm{NH}_{4}^{+} \\
\left(\mathrm{mg} \mathrm{kg}^{-1}\right)\end{array}$ & Av.P (mg kg $\left.{ }^{-1}\right)$ \\
\hline Unpolluted canal & $5.4 \pm 0.2^{a}$ & $0.6 \pm 0.1^{b}$ & $0.3 \pm 0.2^{b}$ & $6.0 \pm 2.0^{b}$ & $55.5 \pm 5.5^{b}$ & $18.2 \pm 3.4^{\mathrm{ab}}$ \\
\hline Polluted canal & $5.4 \pm 0.1^{\mathrm{a}}$ & $1.5 \pm 0.1^{\mathrm{a}}$ & $1.0 \pm 0.1^{\mathrm{a}}$ & $20.1 \pm 2.5^{\mathrm{a}}$ & $98.3 \pm 11.9^{a}$ & $2.8 \pm 0.6^{\mathrm{b}}$ \\
\hline Paddy field & $5.2 \pm 0.1^{\mathrm{a}}$ & $0.6 \pm 0.0^{b}$ & $0.6 \pm 0.1^{\mathrm{ab}}$ & $8.4 \pm 0.4^{b}$ & $49.2 \pm 7.1^{b}$ & $17.6 \pm 5.7^{\mathrm{ab}}$ \\
\hline Fallow field & $5.3 \pm 0.1^{a}$ & $0.4 \pm 0.0^{b}$ & $0.5 \pm 0.1^{\mathrm{ab}}$ & $7.6 \pm 0.5^{b}$ & $41.9 \pm 9.7^{b}$ & $30.6 \pm 7.6^{a}$ \\
\hline Abandoned field & $5.1 \pm 0.1^{\mathrm{a}}$ & $0.5 \pm 0.0^{b}$ & $0.5 \pm 0.1^{\mathrm{ab}}$ & $7.3 \pm 1.0^{b}$ & $44.0 \pm 3.8^{b}$ & $18.5 \pm 3.3^{\mathrm{ab}}$ \\
\hline
\end{tabular}

Data represent mean \pm s.e., and different letters in the same column indicate significant differences according to Tukey's test $(n=3, p<0.05)$

\subsection{Pyrosequencing Analysis of Bacterial Community}

High-throughput sequencing yielded 2998 OTUs acquired from 15 soil samples. Proteobacteria (43.2\%), Chloroflexi (19.8\%), Acidobacteria (15.8\%), Actinobacteria (5.1\%), and Nitrospirae $(5.0 \%)$ were the dominant phyla identified in this study (Figure 2). In the comparison between the two canal sites, Nitrospirae was more abundant in the polluted canal, and Planctomycetes was more abundant in the unpolluted one. Among the three types of fields, only Actinobacteria were more abundant in the abandoned fields than in the paddy fields. Dominant phyla showed diverse and significant correlations with chemical properties. For example, Proteobacteria had positive correlations with EC, C, and N, but Gemmatimonadetes showed an adverse trend with these nutrients. Furthermore, PCoA was conducted to examine the relationships between the bacterial communities across different soil types. PCoA showed that bacterial community composition was separated by PC1 and PC2 at the species level (Figure 3). The two types of canal soils were separated from the three types of field soils in this regard. ANOSIM revealed that the bacterial communities differed significantly depending on field type $(R=0.746, p=0.0001)$.

\begin{tabular}{|c|c|c|c|c|c|}
\hline & canal & canal & field & field & field \\
\hline Proteobacteria & $45.3^{b}$ & $59.0^{a}$ & $37.9^{b c}$ & $34.7^{c}$ & $39.3^{\text {bc }}$ \\
\hline Chloroflexi & $14.9^{b}$ & $10.1^{\mathrm{b}}$ & $25.9^{\mathrm{a}}$ & $26.3^{a}$ & $21.7^{\mathrm{a}}$ \\
\hline Acidobacteria & $17.2^{\mathrm{a}}$ & $15.3^{\mathrm{a}}$ & $13.0^{\mathrm{a}}$ & $18.2^{\mathrm{a}}$ & $15.4^{\mathrm{a}}$ \\
\hline Actinobacteria & $4.4^{\mathrm{bc}}$ & $1.4^{c}$ & $5.5^{\mathrm{b}}$ & $4.5^{\mathrm{bc}}$ & $9.6^{a}$ \\
\hline Nitrospirae & $4.0^{b}$ & $6.5^{\mathrm{a}}$ & $5.4^{\mathrm{ab}}$ & $5.5^{\mathrm{ab}}$ & $3.8^{\mathrm{b}}$ \\
\hline Planctomycetes & $2.3^{a}$ & $1.3^{b}$ & $2.1^{\mathrm{ab}}$ & $2.0^{\mathrm{ab}}$ & $2.5^{\mathrm{a}}$ \\
\hline Chlorobi & $1.6^{\mathrm{a}}$ & $1.1^{\mathrm{a}}$ & $1.7^{\mathrm{a}}$ & $1.6^{\mathrm{a}}$ & $1.2^{\mathrm{a}}$ \\
\hline Firmicutes & $1.2^{\mathrm{ab}}$ & $0.3^{b}$ & $1.2^{\mathrm{a}}$ & $0.9^{\mathrm{ab}}$ & $1.5^{\mathrm{a}}$ \\
\hline Gemmatimonadetes & $1.5^{\mathrm{a}}$ & $0.2^{\mathrm{b}}$ & $1.1^{\mathrm{a}}$ & $1.6^{\mathrm{a}}$ & $1.4^{\mathrm{a}}$ \\
\hline & \multicolumn{5}{|c|}{$\square$} \\
\hline & & & 30 & \multicolumn{2}{|c|}{$60(\%)$} \\
\hline
\end{tabular}

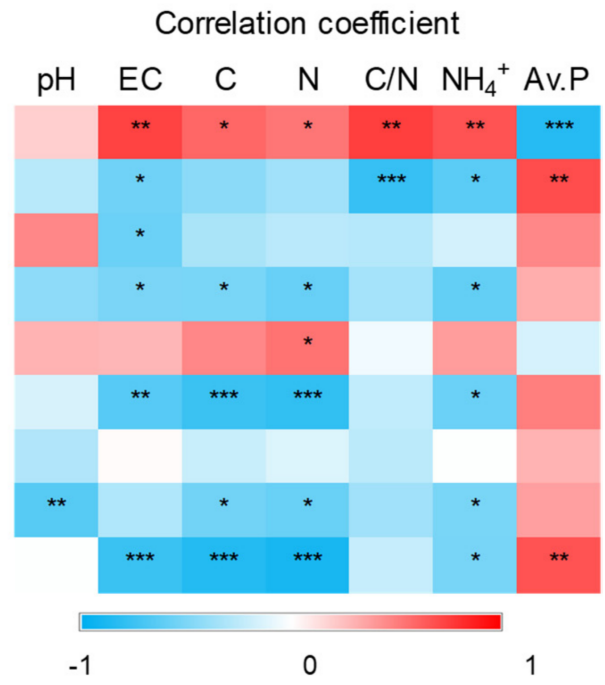

Figure 2. Relative abundance of major phyla and its correlation with soil chemical properties. (left) Relative abundance of bacteria; (right) Spearman's correlation coefficient. Different letters in the same row represent significant differences according to Tukey's test $(n=3, p<0.05)$. ${ }^{*}{ }^{* *}$, and $* * *$ indicate significant correlation at $p<0.05, p<0.01$, and $p<0.001$, respectively. 


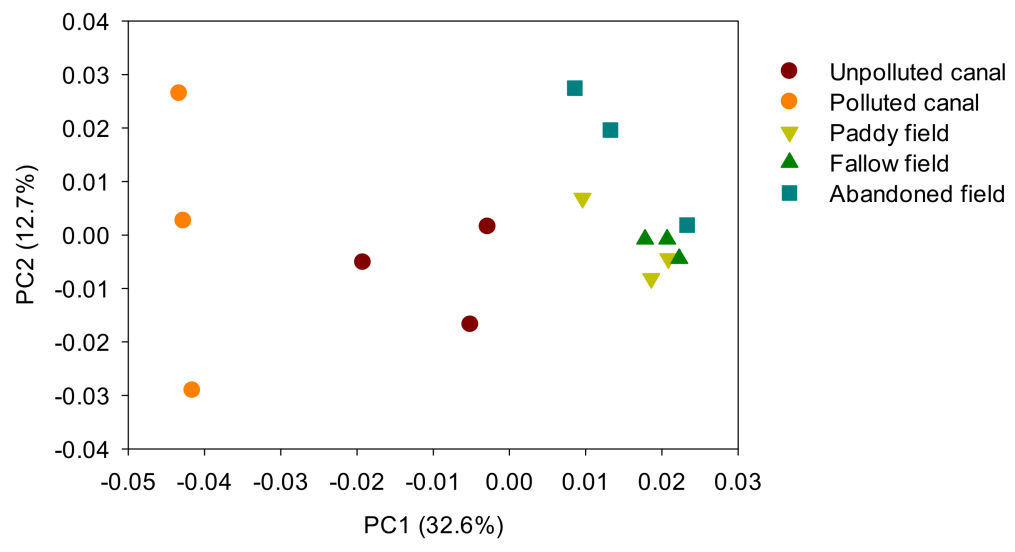

Figure 3. Soil bacterial community analyzed by principal coordinate analysis (PCoA) of UniFrac distances.

\subsection{Taxonomic Diversity}

Taxonomic diversity measured using OTU number and Shannon index were influenced by the type of soil management (Figure 4). The polluted canal showed lower bacterial diversity than the unpolluted one; however, the OTU number did not differ significantly between the two types of soil. Abandoned field soil had 1.7-fold more OTUs than the paddy field soil, and the Shannon index was also higher in the abandoned fields than in the paddy fields. OTU number and diversity indices were correlated with EC and nutrient levels but not significantly correlated with $\mathrm{pH}$ and $\mathrm{C} / \mathrm{N}$ ratio (Figure 5).
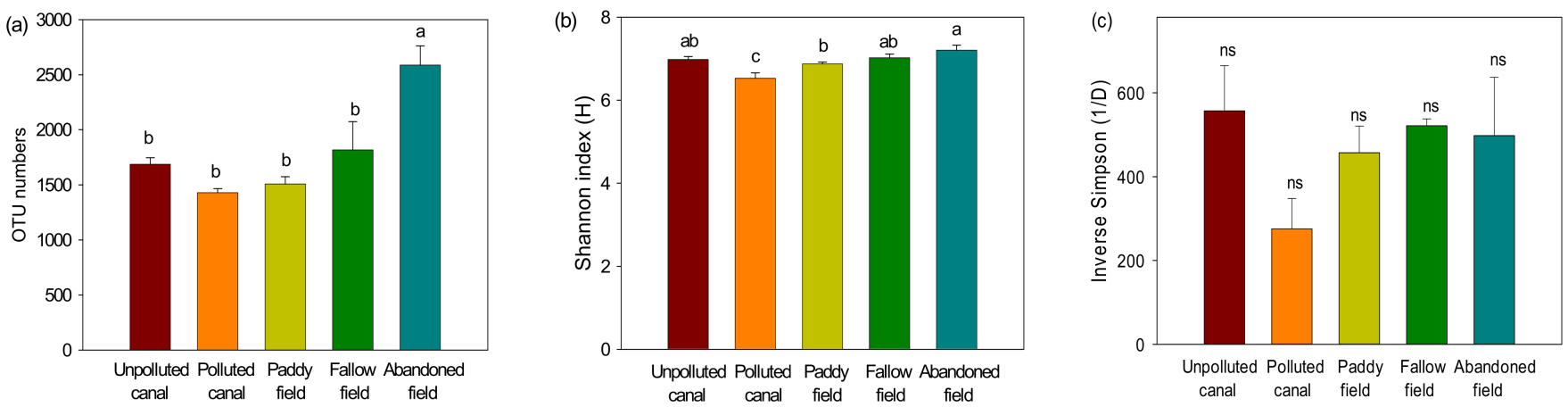

Figure 4. Operational taxonomic unit (OTU) numbers and alpha diversity indices of soil bacterial community as affected by agricultural activities. (a) OTU number, (b) Shannon index, (c) inverse Simpson index. Different letters indicate significant differences (Tukey test, $p<0.05$ ). Each bar represents SE.

\section{Number of OTUs \\ Shannon index $(\mathrm{H})$ \\ Inverse Simpson (1/D)}

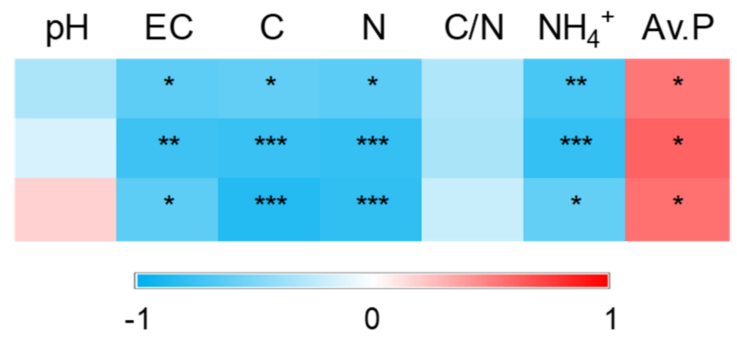

Figure 5. Spearman's correlation coefficient between bacterial taxonomic diversity indices and soil chemical properties. ${ }^{*}, * *$ and ${ }^{* * *}$ indicate significant correlation at $p<0.05, p<0.01$, and $p<0.001$, respectively. 


\subsection{Putative Functions of Soil Bacteria}

A taxa-centered approach using the FAPROTAX system was performed to analyze bacterial functions. It revealed that 11 putative functions were significantly influenced by soil management (Figure 6). Degradation of materials, including cellulose and lignin, was correlated with EC and nutrients. Methanotrophy and nitrate reduction showed a strong positive correlation with EC. KEGG orthologs derived from PICRUSt were used to estimate bacterial genes in relation to soil functioning, and functional diversity was assessed based on the results of FAPROTAX (Figure 7). KEGG pathway analysis revealed that only four functions, including degradation of caprolactam and ethylbenzene, differed significantly by soil type. Soil chemical properties, including EC, $\mathrm{C} / \mathrm{N}$ ratio, and nutrient levels, were partly correlated with these putative functions.

Aerobic anoxygenic phototrophy Aerobic nitrite oxidation

Anoxygenic photoautotrophy $\mathrm{Fe}$ oxidizing Cellulolysis

Dark oxidation of sulfur compounds Dark sulfide oxidation Ligninolysis Methanotrophy Nitrate reduction Sulfate respiration Thiosulfate respiration

\begin{tabular}{ccccc}
$\begin{array}{c}\text { Unpolluted } \\
\text { canal }\end{array}$ & $\begin{array}{c}\text { Polluted } \\
\text { canal }\end{array}$ & $\begin{array}{c}\text { Paddy } \\
\text { field }\end{array}$ & $\begin{array}{c}\text { Fallow } \\
\text { field }\end{array}$ & $\begin{array}{c}\text { Abandoned } \\
\text { field }\end{array}$ \\
$0.0^{\mathrm{b}}$ & $0.0^{\mathrm{b}}$ & $0.4^{\mathrm{ab}}$ & $0.4^{\mathrm{ab}}$ & $0.6^{\mathrm{a}}$ \\
$0.3^{\mathrm{a}}$ & $0.3^{\mathrm{a}}$ & $0.1^{\mathrm{b}}$ & $0.1^{\mathrm{b}}$ & $0.1^{\mathrm{b}}$ \\
$0.1^{\mathrm{b}}$ & $0.0^{\mathrm{b}}$ & $1.1^{\mathrm{ab}}$ & $1.3^{\mathrm{ab}}$ & $1.7^{\mathrm{a}}$ \\
\hline $1.2^{\mathrm{ab}}$ & $2.8^{\mathrm{a}}$ & $0.1^{\mathrm{b}}$ & $0.1^{\mathrm{b}}$ & $0.1^{\mathrm{b}}$ \\
\hline $0.0^{\mathrm{b}}$ & $0.1^{\mathrm{ab}}$ & $0.2^{\mathrm{ab}}$ & $0.3^{\mathrm{a}}$ & $0.2^{\mathrm{ab}}$ \\
$0.0^{\mathrm{b}}$ & $0.1^{\mathrm{ab}}$ & $0.2^{\mathrm{ab}}$ & $0.3^{\mathrm{a}}$ & $0.2^{\mathrm{ab}}$ \\
\hline $1.2^{\mathrm{ab}}$ & $2.8^{\mathrm{a}}$ & $0.1^{\mathrm{b}}$ & $0.1^{\mathrm{b}}$ & $0.1^{\mathrm{b}}$ \\
\hline $1.9^{\mathrm{b}}$ & $4.6^{\mathrm{a}}$ & $1.4^{\mathrm{b}}$ & $0.8^{\mathrm{b}}$ & $1.0^{\mathrm{b}}$ \\
\hline $3.0^{\mathrm{b}}$ & $5.5^{\mathrm{a}}$ & $1.7^{\mathrm{b}}$ & $1.2^{\mathrm{b}}$ & $1.1^{\mathrm{b}}$ \\
\hline $1.5^{\mathrm{ab}}$ & $3.0^{\mathrm{a}}$ & $1.6^{\mathrm{ab}}$ & $1.4^{\mathrm{ab}}$ & $1.0^{\mathrm{b}}$ \\
$1.2^{\mathrm{ab}}$ & $2.5^{\mathrm{a}}$ & $1.2^{\mathrm{ab}}$ & $0.9^{\mathrm{ab}}$ & $0.7^{\mathrm{b}}$ \\
\hline & \multicolumn{5}{c}{$6(\%)$} \\
\hline
\end{tabular}

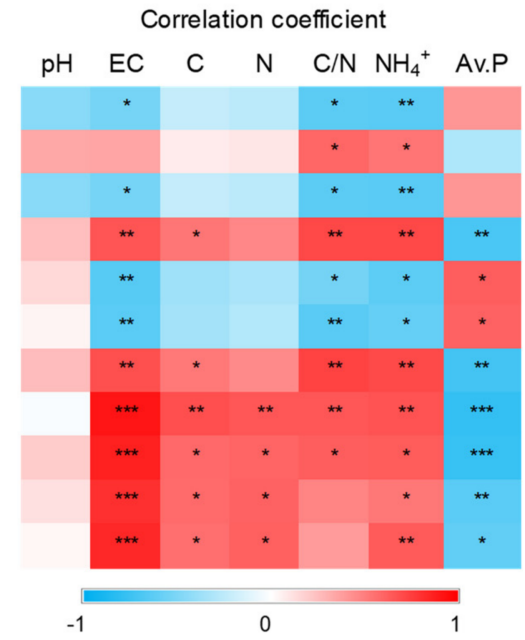

Figure 6. Putative functions of soil bacteria showed significant differences based on Functional Annotation of Prokaryotic Taxa (FAPROTAX) and its correlation with soil chemical properties. (left) Relative abundance of bacteria; (right) Spearman's correlation coefficient. Different letters in the same row indicate significant differences according to Tukey's test $(n=3, p<0.05) .{ }^{*}$, ${ }^{* *}$, and *** indicate significant correlation at $p<0.05, p<0.01$ and $p<0.001$, respectively.

Caprolactam degradation Lysine degradation Ethylbenzene degradation Degradation of aromatic compounds

\begin{tabular}{ccccc}
$\begin{array}{c}\text { Unpolluted } \\
\text { canal }\end{array}$ & $\begin{array}{c}\text { Polluted } \\
\text { canal }\end{array}$ & $\begin{array}{c}\text { Paddy } \\
\text { field }\end{array}$ & $\begin{array}{c}\text { Fallow } \\
\text { field }\end{array}$ & $\begin{array}{c}\text { Abandoned } \\
\text { field }\end{array}$ \\
\hline $0.098^{\mathrm{ab}}$ & $0.087^{\mathrm{b}}$ & $0.103^{\mathrm{a}}$ & $0.104^{\mathrm{a}}$ & $0.107^{\mathrm{a}}$ \\
$0.228^{\mathrm{b}}$ & $0.205^{\mathrm{c}}$ & $0.244^{\mathrm{ab}}$ & $0.246^{\mathrm{a}}$ & $0.249^{\mathrm{a}}$ \\
\hline $0.022^{\mathrm{ab}}$ & $0.020^{\mathrm{b}}$ & $0.025^{\mathrm{a}}$ & $0.022^{\mathrm{ab}}$ & $0.023^{\mathrm{a}}$ \\
\hline $0.616^{\mathrm{ab}}$ & $0.588^{\mathrm{b}}$ & $0.619^{\mathrm{ab}}$ & $0.622^{\mathrm{a}}$ & $0.623^{\mathrm{a}}$ \\
\hline
\end{tabular}

0.4 $0.8(\%)$

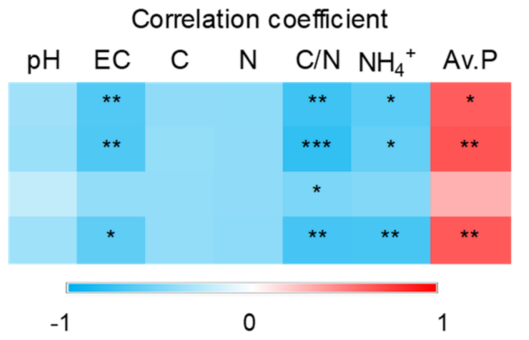

Figure 7. Putative functions of soil bacteria showed significant differences based on the Kyoto Encyclopedia of Genes and Genomes (KEGG) pathway and its correlation with soil chemical properties. (left) Relative abundance of bacteria; (right) Spearman's correlation coefficient. Different letters in the same row represent significant differences according to Tukey's test $(n=3, p<0.05) .{ }^{*}$, **, and *** indicate significant correlation at $p<0.05, p<0.01$ and $p<0.001$, respectively.

\subsection{Diversity of Putative Function}

Functional diversity was predicted according to FAPROTAX analysis. No significant difference was found in the number of bacterial functions (Figure 8). However, the Shannon index was higher in the polluted canal soil than in the unpolluted canal soil, and it was greater in the paddy fields than in the abandoned fields. Diversity indices were partly correlated with EC, C/N ratio, and nutrients (Figure 9). 

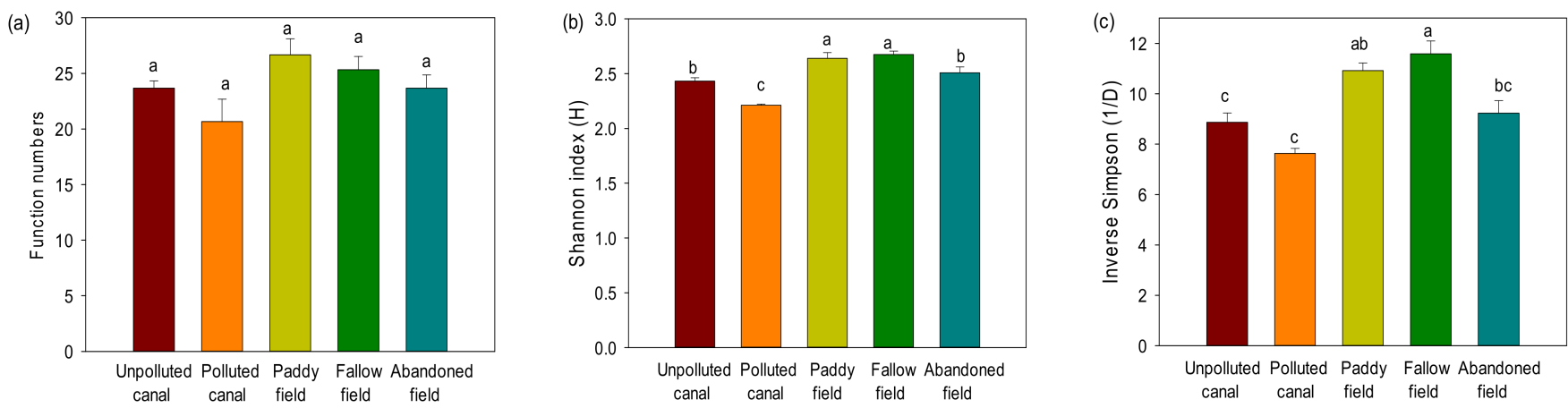

Figure 8. Alpha diversity indices of soil bacterial function in flooded soils. (a) Function number, (b) Shannon index, (c) inverse Simpson index. Different letters indicate significant differences (Tukey test, $p<0.05)$. Each bar represents SE.

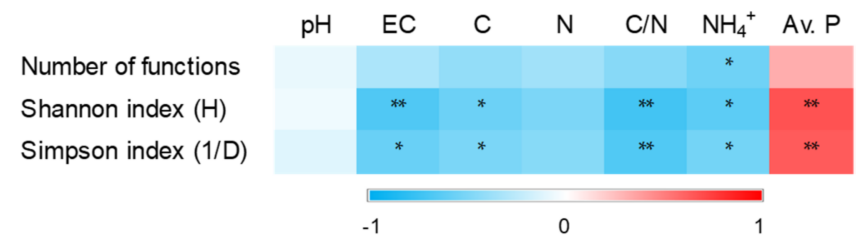

Figure 9. Spearman's correlation coefficient between functional diversity indices of bacteria and soil chemical properties. ${ }^{*}$ and ${ }^{* *}$ indicate significant correlation at $p<0.05$ and $p<0.01$, respectively.

\section{Discussion}

The relative abundance of some bacterial phyla was markedly correlated with C, $\mathrm{N}$, and $\mathrm{P}$ concentrations, suggesting that nutrients were the main influencing factors of bacterial community composition. Bacterial phyla are classified into copiotrophs and oligotrophs according to substrate affinity and life strategies [36]. The fact that Proteobacteria was the most abundant phylum in polluted canal soil with high nutrient levels suggests that this phylum comprises copiotrophic bacteria [37]. In contrast, $\mathrm{C}$ and $\mathrm{N}$ had strong negative effects on the abundance of oligotrophic groups, such as Planctomycetes and Gemmatimonadetes [38-40]. Ren et al. [41] reported that the C/N ratio affected Chloroflexi but not Gemmatimonadetes, as observed in the present study, and they suggested that the interaction between $\mathrm{C}$ and $\mathrm{N}$ also influences soil bacteria. $\mathrm{P}$ had contrasting effects on the abundance of bacterial phyla, such as a positive effect on Chloroflexi and a negative effect on Proteobacteria [10]. Remarkably, the two phyla showed the same response to the application of phosphate-solubilizing bacteria [42]. However, many previous studies have reported limited effects of $\mathrm{P}$ on the bacterial community [43-46]. The inconsistent effect of $\mathrm{P}$ observed in the present study is partly explained by its interaction with other components [47]. Li et al. [45] also reported that $\mathrm{P}$ addition affected bacterial community abundance only in combination with $\mathrm{N}$ addition.

Soil C, N, and P exerted various effects on bacterial taxonomic diversity. Soil C has been observed to have an inconsistent correlation with bacterial diversity $[48,49]$. The effects of soil $\mathrm{C}$ on bacterial diversity may be influenced by shifts in $\mathrm{C}$ availability and dynamics [50]. $\mathrm{N}$ seems to be a critical factor in reducing bacterial diversity because $\mathrm{NH}_{4}{ }^{+}$ and total $\mathrm{N}$ were negatively correlated with OTU number and diversity indices [51,52]. P showed positive effects on bacterial diversity, which is not in accordance with previous findings of neutral [53] and negative [54] effects. The positive effect of $\mathrm{P}$ on bacterial diversity may be limited to P-poor conditions, such as those in volcanic soil, because high available $P$ decreases the alpha diversity of soil bacteria [55]. Another explanation for the observed positive effect is that $\mathrm{P}$ may ameliorate the negative effects of $\mathrm{N}$ addition on the soil bacterial community [56]. Moreover, $\mathrm{N}$ influences bacterial diversity in a dose- 
dependent manner because moderate $\mathrm{N}$ addition has a promoting effect, but excessive $\mathrm{N}$ addition showed an inhibitory effect [57].

Notably, the OTU number was 1.7-fold higher in the abandoned fields than in the paddy fields despite no significant difference in nutrient levels. Garcia-Orenes et al. [58] suggested that the bacterial community abundance of abandoned fields may not be fully explained by the soil's chemical and physical properties. Instead, the effects of ceased fertilization on the bacterial community may be altered by vegetation and fallow period [59]. Zhang et al. [60] reported that soil bacterial diversity increased until equilibrium at the late successional stage in abandoned agricultural fields. Abandoned fields showed an early to middle successional stage in the present study, and a prolonged fallow period is likely to further increase bacterial diversity. Plant diversity may have a positive effect on soil bacterial diversity via an increase in soil heterogeneity [61,62]. The shift from mono-cropped rice to diverse natural plant species in the fallow period may induce various bacterial species to flourish because rhizosphere bacteria are specific to plant species [63]. Further research is warranted to separate the effect of soil chemical properties from that of a shift in plant community.

FAPROTAX is useful for identifying functional groups of soil bacteria [64], and it revealed that material cycling was correlated with nutrient contents. $\mathrm{C}$ and $\mathrm{N}$ are fundamental nutrients determining bacterial growth and biomass [65]. The $\mathrm{C} / \mathrm{N}$ ratio showed wider and stronger effects on the putative functions than $\mathrm{C}$ and $\mathrm{N}$ individually did. The $\mathrm{C} / \mathrm{N}$ ratio is known to alter specific bacterial functions, including nitrification, and a reduction in the $\mathrm{C} / \mathrm{N}$ ratio enriched rare taxa that use ammonium and nitrite in previous studies $[66,67]$. The correlation of the $\mathrm{C} / \mathrm{N}$ ratio with aerobic nitrite oxidation and nitrate reduction demonstrates its effects on $\mathrm{N}$ cycling. $\mathrm{N}$ fertilization increases the abundance of bacterial genes related to $\mathrm{N}$ metabolism, including denitrification and nitrate reduction [45]. The positive correlation of nitrate reduction with $\mathrm{N}$ and $\mathrm{NH}_{4}{ }^{+}$levels indicates that bacterial function is dependent on the input of raw materials. $\mathrm{NH}_{4}^{+}$was positively correlated with cellulose and lignin degradation, which is in contrast with the finding of a previous study [68]. The discrepancy is partly explained by the fact that the effect of $\mathrm{N}$ on bacteria may be altered by the N/P ratio and individual levels of $\mathrm{N}$ and $\mathrm{P}$ [69].

The data obtained using KEGG pathway analysis were used to fully assess the putative functions of unculturable bacteria. However, it did not work as well for soil samples as in previous reports [63,70]. Damon et al. [71] listed 23 types of functions in relation to soil nutrients; however, only a few functions significantly differed among groups in this study. Bacterial degradation of pollutants, including caprolactam and aromatic compounds, was associated with EC and the $\mathrm{C} / \mathrm{N}$ ratio. Hickman and Reid [72] also reported that nutrient levels and the $\mathrm{C} / \mathrm{N}$ ratio influenced bacterial degradation of organic pollutants. Degradation of xenobiotic and toxic materials may assist ecosystem restoration against chemical disturbance.

Species diversity indices can be applied to categorical traits to assess functional diversity [73]. FAPROTAX was used to investigate the changes in the functional diversity of bacteria because it is generally adopted to explore bacterial functions in biogeochemical cycling. The Shannon index was higher for taxonomic and functional diversity in unpolluted canal soil than polluted canal soil, suggesting an ecological link between the two traits [74,75]. However, the comparison between paddy fields and abandoned fields showed a contrasting result for the Shannon index for the two types of diversity. The discrepancy is partly explained by the fact that rice cultivation provides more variable resources and heterogeneity in the chemical and physical properties of soil, and its promoting effect was diminished by the fallow period [76]. Functional diversity is not necessarily associated with taxonomic diversity $[77,78]$. Functional diversity may depend on the amount of effective resources; for example, in a previous study, functional diversity was increased only under intermediate $\mathrm{N}$ input [79]. The change in functional diversity was not concomitant with taxonomical diversity in response to rice cultivation history. The decoupled response reflects a weak link between the two variables and can be explained 
by function redundancy [32,80]. Moreover, Cheaib et al. [81] suggested that decoupling taxonomic and functional variation reflects an adaptive signature of the microbial community. Experimental studies demonstrating linkages between bacterial diversity and the performance of metabolic processes have been reported [82-84]. However, little is known about the impact of decoupling on metabolic functions, requiring further studies to explore how it influences the stability of ecosystem functioning.

The function-based approach combined with taxonomic information is critical to ecological strategies for restoring bacterial diversity. However, decoupling in diversity traits makes biodiversity target selection challenging. For example, this study's taxabased analysis of functional diversity has limited physiological and metabolic information. Instead, taxonomic diversity has been traditionally used for measuring biodiversity and may be a primary target in ecological engineering. Soil bacterial community diversity is an indicator of wetland soil restoration [85]. Practical strategies are needed to restore soil bacterial diversity, which provides valuable archaeological and geochemical information [7]. Some studies tried to reconstruct the soil bacterial community prior to the agricultural era [48]. Long-term fallow of rice fields may restore soil bacterial taxonomic diversity. The increase in OTU number and some diversity indices by the cessation of cultivation observed in this study support this concept. Leaving a field fallow has been shown to be beneficial for maintaining soil bacterial diversity [37]. Our results imply that leaving a field fallow may not be effective in a short period, and changes in soil properties after cessation of cultivation may be gradual [86]. Moreover, it should be considered that the practice of fallow may have adverse effects on the functional diversity of soil bacteria. The other option is to manage fertilization by decreasing $\mathrm{N}$ input and supplementing $\mathrm{P}$ in rice cultivation. An overdose of $\mathrm{N}$ fertilizers has been a concern, and $\mathrm{N}$ input needs to be decreased. The effect of P supplementation seems to be limited to P-deficient environments, and its effect can be altered through interaction with other nutrients.

\section{Conclusions}

We observed that agricultural land use in the Hanon Marr crater altered the soil bacterial community composition and diversity. This study demonstrated that $\mathrm{C}, \mathrm{N}$, and $\mathrm{P}$ were the main nutrient factors influencing the bacterial community. Our genomic analysis of the bacterial community revealed that taxonomic and functional diversity showed a decoupled response to rice cultivation, suggesting a weak linkage between them. Therefore, improving taxonomic diversity could be a preferable goal for restoring bacterial diversity. Our results propose that it can be accomplished by long-term fallow. Furthermore, we provide the following recommendations for soil amendment to improve bacterial diversity:

- Keeping land fallow for more than 5 years.

- Reducing the input of $\mathrm{C}$ and $\mathrm{N}$ from fertilizers.

o Supplementing P in P-deficient soil.

Author Contributions: Conceptualization, J.E. and M.-H.K.; methodology, J.E. and M.-H.K.; formal analysis, J.E.; investigation, J.E. and M.-H.K.; data curation, J.E.; writing-original, J.E. All authors have read and agreed to the published version of the manuscript.

Funding: This study was carried out with the support of "Research Program for Agricultural Science \& Technology Development (Project No. PJ01507302), National Institute of Agricultural Sciences, Rural Development Administration, Republic of Korea".

Institutional Review Board Statement: Not applicable.

Informed Consent Statement: Not applicable.

Data Availability Statement: Not applicable.

Conflicts of Interest: The authors declare no conflict of interest. 


\section{References}

1. Beget, J.E.; Hopkins, D.M.; Charron, S.D. The Largest Known Maars on Earth, Seward Peninsula, Northwest Alaska. Arctic 1996, 49, 62-69. [CrossRef]

2. Yoon, S.H.; Lee, B.G.; Sohn, Y.K. Geomorphic and geological characteristics and eruption process of the Hanon volcano, Jeju Island. J. Geol. Soc. Korea 2006, 42, 19-30.

3. Bowers, K.; Kim, E.S.; Yang, Y.C.; Lee, S.C. A study on restoration plans of Jeju Hanon maar crater. World Environ. Isl. Stud. 2014, $4,45-82$.

4. Kim, M.; Nam, H.; Eo, J.; Kwon, S.; Song, Y. Flora and restoration plan of Hanon paddy fields made in maar crater, Jeju island, South Korea. Korea J. Environ. Biol. 2018, 36, 439-455. [CrossRef]

5. Barluenga, M.; Stölting, K.N.; Salzburger, W.; Muschick, M.; Meyer, A. Sympatric speciation in Nicaraguan crater lake cichlid fish. Nature 2006, 439, 719-723. [CrossRef] [PubMed]

6. Lanzén, A.; Simachew, A.; Gessesse, A.; Chmolowska, D.; Jonassen, I.; Øvreås, L. Surprising Prokaryotic and Eukaryotic Diversity, Community Structure and Biogeography of Ethiopian Soda Lakes. PLoS ONE 2013, 8, e72577. [CrossRef] [PubMed]

7. Chung, C.-H. Vegetation response to climate change on Jeju Island, South Korea, during the last deglaciation based on pollen record. Geosci. J. 2007, 11, 147-155. [CrossRef]

8. Trivedi, P.; Delgado-Baquerizo, M.; Jeffries, T.C.; Trivedi, C.; Anderson, I.C.; Lai, K.; McNee, M.; Flower, K.; Singh, B.P.; Minkey, D.; et al. Soil aggregation and associated microbial communities modify the impact of agricultural management on carbon content. Environ. Microbiol. 2017, 19, 3070-3086. [CrossRef] [PubMed]

9. Chiba, A.; Uchida, Y.; Kublik, S.; Vestergaard, G.; Buegger, F.; Schloter, M.; Schulz, S. Soil bacterial diversity is positively correlated with decomposition rates during early phases of maize litter decomposition. Microorganisms 2021, 9, 357. [CrossRef]

10. Eo, J.; Park, K.-C. Long-term effects of imbalanced fertilization on the composition and diversity of soil bacterial community. Agric. Ecosyst. Environ. 2016, 231, 176-182. [CrossRef]

11. Singh, B. Are nitrogen fertilizers deleterious to soil health? Agronomy 2018, 8, 48. [CrossRef]

12. Adekiya, A.O.; Ejue, W.S.; Olayanju, A.; Dunsin, O.; Aboyeji, C.M.; Aremu, C.; Adegbite, K.; Akinpelu, O. Different organic manure sources and NPK fertilizer on soil chemical properties, growth, yield and quality of okra. Sci. Rep. 2020, 10, 16083. [CrossRef]

13. Zhu, Z.L.; Chen, D.L. Nitrogen fertilizer use in China: Contributions to food production impacts on the environment strategies. Nutr. Cycl. Agroecosystems 2002, 63, 117-127. [CrossRef]

14. Dybowski, D.; Dzierzbicka-Glowacka, L.A.; Pietrzak, S.; Juszkowska, D.; Puszkarczuk, T. Estimation of nitrogen leaching load from agricultural fields in the Puck Commune with an interactive calculator. Peer] 2020, 8, e8899. [CrossRef] [PubMed]

15. Wade, M.R.; Gurr, G.M.; Wratten, S.D. Ecological restoration of farmland: Progress and Prospects. Philos. Trans. R. Soc. B Biol. Sci. 2008, 363, 831-847. [CrossRef]

16. Pander, J.; Geist, J. Ecological indicators for stream restoration success. Ecol. Indic. 2013, 30, 106-118. [CrossRef]

17. Benayas, J.M.R.; Newton, A.C.; Diaz, A.; Bullock, J.M. Enhancement of biodiversity and ecosystem services by ecological res-toration: A Meta-Analysis. Science 2009, 325, 1121-1124. [CrossRef]

18. Laurila-Panta, M.; Lehikoinen, A.; Uusitalo, L.; Venesjarvi, R. How to value biodiversity in environmental management? Ecol. Indic. 2015, 55, 1-11. [CrossRef]

19. Kennedy, A.C.; Smith, K.L. Soil microbial diversity and the sustainability of agricultural soils. Plant Soil 1995, 170, 75-86. [CrossRef]

20. Griffiths, B.S.; Philippot, L. Insights into the resistance and resilience of the soil microbial community. FEMS Microbiol. Rev. 2013, 37, 112-129. [CrossRef]

21. Tautges, N.E.; Sullivan, T.S.; Reardon, C.L.; Burke, I.C. Soil microbial diversity and activity linked to crop yield and quality in a dryland organic wheat production system. Appl. Soil Ecol. 2016, 108, 258-268. [CrossRef]

22. Chen, Y.-P.; Tsai, C.-F.; Rekha, P.D.; Ghate, S.D.; Huang, H.-Y.; Hsu, Y.-H.; Liaw, L.-L.; Young, C.-C. Agricultural management practices influence the soil enzyme activity and bacterial community structure in tea plantations. Bot. Stud. 2021, 62, 8. [CrossRef] [PubMed]

23. Wang, L.; Huang, D. Nitrogen and phosphorus losses by surface runoff and soil microbial communities in a paddy field with different irrigation and fertilization managements. PLOS ONE 2021, 16, e0254227. [CrossRef] [PubMed]

24. Ullah, S.; He, P.; Ai, C.; Zhao, S.; Ding, W.; Song, D.; Zhang, J.; Huang, S.; Abbas, T.; Zhou, W. How do soil bacterial diversity and community composition respond under recommended and conventional nitrogen fertilization regimes? Microorganisms 2020, 8, 1193. [CrossRef]

25. Pulleman, M.; Creamer, R.; Hamer, U.; Helder, J.; Pelosi, C.; Peres, G.; Rutgers, M. Soil biodiversity, biological indicators and soil ecosystem services-An overview of European approaches. Curr. Opin. Environ. Sustain. 2012, 4, 529-538. [CrossRef]

26. Behnke, G.D.; Kim, N.; Zabaloy, M.; Riggins, C.W.; Rodriguez-Zas, S.; Villamil, M.B. Soil Microbial Indicators within Rotations and Tillage Systems. Microorganisms 2021, 9, 1244. [CrossRef]

27. Checcucci, A.; Luise, D.; Modesto, M.; Correa, F.; Bosi, P.; Mattarelli, P.; Trevisi, P. Assessment of Biolog EcoplateTM method for functional metabolic diversity of aerotolerant pig fecal microbiota. Appl. Microbiol. Biotechnol. 2021, 105, 6033-6045. [CrossRef]

28. Kang, D.; Jacquiod, S.; Herschend, J.; Wei, S.; Nesme, J.; Sørensen, S.J. Construction of Simplified Microbial Consortia to Degrade Recalcitrant Materials Based on Enrichment and Dilution-to-Extinction Cultures. Front. Microbiol. 2020, 10, 3010. [CrossRef] 
29. Fadrosh, D.W.; Ma, B.; Gajer, P.; Sengamalay, N.; Ott, S.; Brotman, R.M.; Ravel, J. An improved dual-indexing approach for multiplexed 16S rRNA gene sequencing on the Illumina MiSeq platform. Microbiome 2014, 2, 6. [CrossRef]

30. Edgar, R.C.; Haas, B.J.; Clemente, J.C.; Quince, C.; Knight, R. UCHIME improves sensitivity and speed of chimera detection. Bioinformatics 2011, 27, 2194-2200. [CrossRef]

31. Yoon, S.-H.; Ha, S.-M.; Kwon, S.; Lim, J.; Kim, Y.; Seo, H.; Chun, J. Introducing EzBioCloud: A Taxonomically United Database of 16S rRNA Gene Sequences and Whole-Genome Assemblies. Int. J. Syst. Evol. Microbiol. 2017, 67, 1613-1617. [CrossRef]

32. Louca, S.; Parfrey, L.W.; Doebeli, M. Decoupling function and taxonomy in the global ocean microbiome. Science 2016, 353, 1272-1277. [CrossRef] [PubMed]

33. Kanehisa, M.; Goto, S. KEGG: Kyoto Encyclopedia of Genes and Genomes. Nucleic Acids Res. 2000, 28, 27-30. [CrossRef] [PubMed]

34. Langille, M.G.; Zaneveld, J.; Caporaso, J.G.; McDonald, D.; Knights, D.; Reyes, J.A.; Clemente, J.C.; Burkepile, D.E.; Vega Thurber, R.L.; Knight, R.; et al. Predictive functional profiling of microbial communities using $16 \mathrm{~S}$ rRNA marker gene sequences. Nat. Biotechnol. 2013, 31, 814-821. [CrossRef] [PubMed]

35. Oksanen, J.; Blanchet, G.; Friendly, M.; Kindt, R.; Lagendre, P.; McGlinn, D.; Minchin, P.R.; O’Hara, R.B.; Simpson, G.; Solymos, P. Vegan: Community Ecology, R Package. Available online: https://craan.r-project.org/web/packages/vegta/vegan (accessed on 8 December 2021).

36. Ho, A.; Di Lonardo, D.P.; Bodelier, P.L.E. Revisiting life strategy concepts in environmental microbial ecology. FEMS Microbiol. Ecol. 2017, 93. [CrossRef]

37. Xun, W.; Zhao, J.; Xue, C.; Zhang, G.; Ran, W.; Wang, B.; Shen, Q.; Zhang, R. Significant alteration of soil bacterial communities and organic carbon decomposition by different long-term fertilization management conditions of extremely low-productivity arable soil in South China. Environ. Microbiol. 2016, 18, 1907-1917. [CrossRef]

38. Li, F.; Chen, L.; Zhang, J.; Yin, J.; Huang, S. Bacterial Community Structure after Long-term Organic and Inorganic Fertilization Reveals Important Associations between Soil Nutrients and Specific Taxa Involved in Nutrient Transformations. Front. Microbiol. 2017, 8, 187. [CrossRef]

39. Yao, F.; Yang, S.; Wang, Z.; Wang, X.; Ye, J.; Wang, X.; DeBruyn, J.M.; Feng, X.; Jiang, Y.; Li, H. Microbial Taxa Distribution Is Associated with Ecological Trophic Cascades along an Elevation Gradient. Front. Microbiol. 2017, 8, 2071. [CrossRef]

40. Will, C.; Thurmer, A.; Wollherr, A.; Nacke, H.; Herold, N.; Schrumpf, M.; Gutknecht, J.; Wubet, T.; Buscot, F.; Daniel, R. Horizonspecific community composition of German grassland soils, as revealed by pyrosequencing-based analysis of $16 \mathrm{~S}$ rDNA genes. Appl. Environ. Microb. 2010, 76, 6751-6759. [CrossRef]

41. Ren, N.; Wang, Y.; Ye, Y.; Zhao, Y.; Huang, Y.; Fu, W.; Chu, X. Effects of continuous nitrogen fertilizer application on the di-versity and composition of rhizosphere soil bacteria. Front. Microbiol. 2020, 11, 1948. [CrossRef]

42. Song, J.; Min, L.; Wu, J.; He, Q.; Chen, F.; Wang, Y. Response of the microbial community to phosphate-solubilizing bacterial inoculants on Ulmus chenmoui Cheng in Eastern China. PLoS ONE 2021, 16, e0247309. [CrossRef] [PubMed]

43. Wang, Q.; Wang, C.; Yu, W.; Turak, A.; Chen, D.; Huang, Y.; Ao, J.; Jiang, Y.; Huang, Z. Effects of Nitrogen and Phosphorus Inputs on Soil Bacterial Abundance, Diversity, and Community Composition in Chinese Fir Plantations. Front. Microbiol. 2018, 9 , 1543. [CrossRef] [PubMed]

44. Leff, J.W.; Jones, S.E.; Prober, S.M.; Barberán, A.; Borer, E.T.; Firn, J.; Harpole, W.S.; Hobbie, S.; Hofmockel, K.; Knops, J.M.H.; et al. Consistent responses of soil microbial communities to elevated nutrient inputs in grasslands across the globe. Proc. Natl. Acad. Sci. USA 2015, 112, 10967-10972. [CrossRef] [PubMed]

45. Li, Y.; Tremblay, J.; Bainard, L.D.; Cade-Menun, B.; Hamel, C. Long-term effects of nitrogen and phosphorus fertilization on soil microbial community structure and function under continuous wheat production. Environ. Microbiol. 2020, 22, 1066-1088. [CrossRef] [PubMed]

46. Zhang, X.; Chen, Q.; Han, X. Soil Bacterial Communities Respond to Mowing and Nutrient Addition in a Steppe Ecosystem. PLoS ONE 2013, 8, e84210. [CrossRef]

47. Thirukkumaran, C.M.; Parkinson, D. Microbial respiration, biomass, metabolic quotient and litter decomposition in a lodgepole pine forest floor amended with nitrogen and phosphorous fertilizers. Soil Biol. Biochem. 2000, 32, 59-66. [CrossRef]

48. Fierer, N.; Jackson, R.B. The diversity and biogeography of soil bacterial communities. Proc. Natl. Acad. Sci. USA 2006, 103, 626-631. [CrossRef]

49. Delgado-Baquerizo, M.; Maestre, F.T.; Reich, P.B.; Trivedi, P.; Osanai, Y.; Liu, Y.; Hamonts, K.; Jeffries, T.C.; Singh, B.K. Carbon content and climate variability drive global soil bacterial diversity patterns. Ecol. Monogr. 2016, 86, 373-390. [CrossRef]

50. Fierer, N.; Ladau, J.; Clemente, J.C.; Leff, J.W.; Owens, S.M.; Pollard, K.S.; Knight, R.; Gilbert, J.A.; McCulley, R.L. Reconstructing the microbial diversity and function of pre-agricultural tallgrass prairie soils in the United States. Science 2013, 342, 621-624. [CrossRef]

51. Zeng, J.; Liu, X.; Song, L.; Lin, X.; Zhang, H.; Shen, C.; Chu, H. Nitrogen fertilization directly affects soil bacterial diversity and indirectly affects bacterial community composition. Soil Biol. Biochem. 2015, 92, 41-49. [CrossRef]

52. Liang, R.; Hou, R.; Li, J.; Lyu, Y.; Hang, S.; Gong, H.; Ouyang, Z. Effects of different fertilizers on rhizosphere bacterial communities of winter wheat in the North China plain. Agronomy 2020, 10, 93. [CrossRef]

53. Wang, Y.; Zhao, X.; Guo, Z.; Jia, Z.; Wang, S.; Ding, K. Response of soil microbes to a reduction in phosphorus fertilizer in rice-wheat rotation paddy soils with varying soil P levels. Soil Tillage Res. 2018, 181, 127-135. [CrossRef] 
54. Pathan, S.I.; Scibetta, S.; Grassi, C.; Pietramellara, G.; Orlandini, S.; Ceccherini, M.T.; Napoli, M. Response of soil bacterial community to application to organic and inorganic phosphate based fertilizers under Vicia faba L. cultivation at two different phenological stages. Sustainability 2020, 12, 9706. [CrossRef]

55. Liu, C.; Zhao, X.; Lin, Q.; Li, G. Decrease in diversity and shift in composition of the soil bacterial community were closely related to high available phosphorus in agricultural Fluvisols of North China. Acta Agric. Scand. Sect. B-Soil Plant Sci. 2019, 69, 618-630. [CrossRef]

56. Xia, Z.; Yang, J.; Sang, C.; Wang, X.; Sun, L.; Jiang, P.; Wang, C.; Bai, E. Phosphorus Reduces Negative Effects of Nitrogen Addition on Soil Microbial Communities and Functions. Microorganisms 2020, 8, 1828. [CrossRef] [PubMed]

57. Sun, S.; Xing, F.; Zhao, H.; Gao, Y.; Bai, Z.; Dong, Y. Response of bacterial community to simulated nitrogen deposition in soils and a unique relationship between plant species and soil bacteria in the Songnen grassland in Northeastern China. J. Soil Sci. Plant Nutr. 2014, 14, 565-580. [CrossRef]

58. García-Orenes, F.; Morugán-Coronado, A.; Zornoza, R.; Scow, K. Changes in Soil Microbial Community Structure Influenced by Agricultural Management Practices in a Mediterranean Agro-Ecosystem. PLoS ONE 2013, 8, e80522. [CrossRef] [PubMed]

59. Li, G.; Zhang, M.; Wu, C. Short-term fallow practices drive soil bacterial community changes: A case study from China. Appl. Soil Ecol. 2021, 165, 103988. [CrossRef]

60. Zhang, K.; Cheng, X.; Shu, X.; Liu, Y.; Zhang, Q. Linking soil bacterial and fungal communities to vegetation succession following agricultural abandonment. Plant Soil 2018, 431, 19-36. [CrossRef]

61. Liu, L.; Zhu, K.; Wurzburger, N.; Zhang, J. Relationships between plant diversity and soil microbial diversity vary across taxonomic groups and spatial scales. Ecosphere 2020, 11, e02999. [CrossRef]

62. Curd, E.E.; Martiny, J.B.H.; Li, H.; Smith, T.B. Bacterial diversity is positively correlated with soil heterogeneity. Ecosphere 2018, 9, e02079. [CrossRef]

63. Eo, J.; Kim, M.H.; Kim, M.K.; Choi, S.K. Shift of dominant species in plant community and soil chemical properties shape soil bacterial community characteristics and putative functions: A Case Study on Topographic Variation in a Mountain Pasture. Microorganisms 2021, 9, 961. [CrossRef] [PubMed]

64. Sansupa, C.; Wahdan, S.F.M.; Hossen, S.; Disayathanoowat, T.; Wubet, T.; Purahong, W. Can we use functional annotation of prokaryotic taxa (FAPROTAX) to assign the ecological functions of soil bacteria? Appl. Sci. 2021, 11, 688. [CrossRef]

65. Li, Y.; Wu, J.; Shen, J.; Liu, S.; Wang, C.; Chen, D.; Huang, T.; Zhang, J. Soil microbial C:N ratio is a robust indicator of soil productivity for paddy fields. Sci. Rep. 2016, 6, 35266. [CrossRef] [PubMed]

66. Bengtsso, G.; Bengtson, P.; Mansson, K.F. Gross nitrogen mineralization, immobilization, and nitrification rates as a functional of soil C/N ratio and microbial activity. Soil Biol. Biochem. 2003, 35, 143-154. [CrossRef]

67. Ananderud, Z.; Saurey, S.; Ball, B.A.; Wall, D.H.; Barrett, J.E.; Muscarella, M.E.; Griffin, N.A.; Virainia, R.A.; Barberan, A.; Adams, B.J. Stoichiometric shifts in soil C: N: P promote bacterial taxa dominance, maintain biodiversity, and deconstruct community assemblages. Front Microbiol. 2018, 9, 1401.

68. Entry, J.A. Influence of nitrogen on cellulose and lignin mineralization in blackwater and redwater forested wetland soils. Biol. Fertil. Soils 2000, 31, 436-440. [CrossRef]

69. Güsewell, S.; Gessner, M.O. N:P ratios influence litter decomposition and colonization by fungi and bacteria in microcosms. Funct. Ecol. 2009, 23, 211-219. [CrossRef]

70. Sun, S.; Jones, R.B.; Fodor, A.A. Inference-based accuracy of metagenome prediction tools varies across sample types and functional categories. Microbiome 2020, 8, 46. [CrossRef] [PubMed]

71. Damon, C.; Lehembre, F.; Oger-Desfeux, C.; Luis, P.; Ranger, J.; Fraissinet-Tachet, L.; Marmeisse, R. Metatranscriptomics Reveals the Diversity of Genes Expressed by Eukaryotes in Forest Soils. PLoS ONE 2012, 7, e28967. [CrossRef] [PubMed]

72. Hickman, Z.A.; Reid, B.J. Increased microbial catabolic activity in diesel contaminated soil following addition of earthworms (Dendrobaena veneta) and compost. Soil Biol. Biochem. 2008, 40, 2970-2976. [CrossRef]

73. Schleuter, D.; Daufresne, M.; Massol, F.; Argillier, C. A user's guide to functional diversity indices. Ecol. Monogr. 2010, 80, 469-484. [CrossRef]

74. Fierer, N.; Leff, J.W.; Adams, B.J.; Nielsen, U.N.; Bates, S.T.; Lauber, C.L.; Owens, S.; Gilbert, J.A.; Wall, D.H.; Caporaso, J.G. Cross-biome metagenomic analyses of soil microbial communities and their functional attributes. Proc. Natl. Acad. Sci. USA 2012, 109, 21390-21395. [CrossRef] [PubMed]

75. Gilbert, J.A.; Field, D.; Swift, P.; Thomas, S.; Cummings, D.; Temperton, B.; Weynberg, K.; Huse, S.; Hughes, M.; Joint, I.; et al. The Taxonomic and Functional Diversity of Microbes at a Temperate Coastal Site: A 'Multi-Omic' Study of Seasonal and Diel Temporal Variation. PLoS ONE 2010, 5, e15545. [CrossRef] [PubMed]

76. Trivedi, P.; Delgado-Baquerizo, M.; Anderson, I.C.; Singh, B.K. Response of soil properties and microbial communities to ag-riculture: Implications for Primary Productivity and Soil Health Indicators. Front. Plant Sci. 2016, 7, 990. [CrossRef] [PubMed]

77. Souza, R.C.; Mendes, C.; Reis-Junior, F.B.; Carvalho, F.M.; Nogueira, M.A.; Vasconcelos, A.T.R.; Vicente, V.A.; Hungria, M. Shifts in taxonomic and functional microbial diversity with agriculture: How fragile is the Brazilian Cerrado? BMC Microbiol. 2016, 16, 42. [CrossRef] [PubMed]

78. He, X.-Y.; Wang, K.-L.; Zhang, W.; Chen, Z.-H.; Zhu, Y.-G.; Chen, H.-S. Positive correlation between soil bacterial metabolic and plant species diversity and bacterial and fungal diversity in a vegetation succession on Karst. Plant Soil 2008, 307, 123-134. [CrossRef] 
79. Zhang, X.; Johnston, E.R.; Barberán, A.; Ren, Y.; Wang, Z.; Han, X. Effect of intermediate disturbance on soil microbial functional diversity depends on the amount of effective resources. Environ. Microbiol. 2018, 20, 3862-3875. [CrossRef] [PubMed]

80. Roth-Schulze, A.J.; Zozaya-Valdes, E.; Steinberg, P.D.; Thomas, T. Partitionaing of functional and taxonomic diversity in surfaceassociated microbial communities. Environ. Microbiol. 2016, 18, 4391-4402. [CrossRef] [PubMed]

81. Cheaib, B.; Le Boulch, M.; Mercier, P.; Derome, N. Taxon-function decoupling as an adaptive signature of lake microbial metacommunites under a chronic polymetallic pollution gradient. Front. Microbiol. 2018, 9, 869. [CrossRef]

82. Kiersztyn, B.; Chróst, R.; Kaliński, T.; Siuda, W.; Bukowska, A.; Kowalczyk, G.; Grabowska, K. Structural and functional microbial diversity along a eutrophication gradient of interconnected lakes undergoing anthropopressure. Sci. Rep. 2019, 9, 11144. [CrossRef] [PubMed]

83. Trivedi, C.; Delgado-Baquerizo, M.; Hamonts, K.; Lai, K.; Reich, P.B.; Singh, B.K. Losses in microbial functional diversity reduce the rate of key soil processes. Soil Biol. Biochem. 2019, 135, 267-274. [CrossRef]

84. Philippot, L.; Spor, A.; Hénault, C.; Bru, D.; Bizouard, F.; Jones, C.M.; Sarr, A.; Maron, P.-A. Loss in microbial diversity affects nitrogen cycling in soil. ISME J. 2013, 7, 1609-1619. [CrossRef] [PubMed]

85. Hartman, W.H.; Richardson, C.J.; Vilgalys, R.; Bruland, G.L. Environmental and anthropogenic controls over bacterial communities in wetland soils. Proc. Natl. Acad. Sci. USA 2008, 105, 17842-17847. [CrossRef]

86. Jangid, K.; Williams, M.A.; Franzluebbers, A.J.; Blair, J.M.; Coleman, D.C.; Whitman, W.B. Development of soil microbial communities during tallgrass prairie restoration. Soil Biol. Biochem. 2010, 42, 302-312. [CrossRef] 